Indonesian Journal of Electronics and Instrumentation Systems (IJEIS)

Vol.10, No.2, October 2020, pp. 189 198

ISSN (print): 2088-3714, ISSN (online): 2460-7681

DOI: https://doi.org/10.22146/ijeis.59588

\title{
Klasifikasi Tingkat Kekakuan Dinding Beton Terhadap Getaran Dengan Metode K-Nearest Neighbor
}

\author{
Mochammad Shidqi Taufiqurrahman*1, Lukman Awaludin ${ }^{2}$ \\ ${ }^{1}$ Program Studi Elektronika dan Instrumentasi, FMIPA, UGM, Yogyakarta, Indonesia \\ ${ }^{2}$ Departemen Ilmu Komputer dan Elektronika, FMIPA UGM, Yogyakarta, Indonesia \\ e-mail: *11m.shidqi@mail.ugm.ac.id, ${ }^{2}$ lukman.awaludin@ugm.ac.id
}

Abstrak

Rendahnya tingkat kekakuan dinding dapat mengakibatkan kerusakan pada bangunan saat terjadi gempa bumi dengan skala yang besar. Terdapat banyak sistem pengukuran tingkat kekakuan pada bangunan namun belum mencapai tahap klasifikasi. Oleh sebab itu, diperlukan sistem yang dapat mengklasifikasikan tingkat kekakuan untuk mengetahui dampak getaran terhadap dinding agar dapat meminimalisir kerugian yang ditimbulkan.

Penelitian ini membuat sistem yang dapat mengklasifikasikan tingkat kekakuan dinding dengan menggunakan metode k-Nearest Neighbor (KNN) ke dalam beberapa kategori (aman, rawan, bahaya, dan hancur). Data yang diambil pada tahap akuisisi adalah ground acceleration, inclination angle, displacement, drift ratio, dan nilai puncak. Masukan KNN berupa nilai peak ground acceleration yang menyebabkan drift ratio sebesar 1\%. Keluaran yang dihasilkan adalah kategori tingkat kekakuan dinding berdasarkan Skala Intensitas Gempabumi oleh BMKG.

Secara fungsional, sistem yang dirancang mampu mengklasifikasikan tingkat kekakuan dinding dengan masukan data non-linear menggunakan metode K-Nearest Neighbor (KNN). Tingkat keberhasilan KNN mencapai nilai 100\%. Berdasarkan hasil pembacaan PGA drift ratio, diasumsikan dinding dapat menahan getaran maksimal dengan nilai PGA drift ratio sebesar $0.34 \mathrm{~g}$ tanpa menimbulkan kerusakan pada dinding sekalipun memiliki tingkat kekakuan yang rendah. Pengujian pada dinding mendapatkan tingkat presisi kurang tinggi. Hal ini mungkin dikarenakan adanya faktor selain PGA yang dapat mempengaruhi drift ratio pada dinding, yang belum dipertimbangkan dalam penelitian ini.

Kata kunci - KNN, Sensor IMU, Kekakuan Dinding, PGA

Abstract
The low level of wall stiffness can cause damage to buildings during large-scale earthquakes. There are many systems for measuring the level of stiffness in buildings, but they have not yet reached the classification stage. Therefore, a system that can classify stiffness is needed to determine the impact of vibrations on the wall to minimize the losses incurred.

This study creates a system that can classify the level of wall stiffness using the $K$ Nearest Neighbor (KNN) method into several categories (safe, vulnerable, dangerous, and destroyed). The data taken at the acquisition stage are ground acceleration, inclination angle, displacement, drift ratio, and peak value. The KNN input is a peak ground acceleration value, which causes a drift ratio of 1\%. The resulting output is a category of wall stiffness based on the Earthquake Intensity Scale by BMKG.

Functionally, the system designed can classify wall stiffness with non-linear data input using the K-Nearest Neighbor (KNN) method. The success rate of KNN reaches a value of $100 \%$. Based on the PGA drift ratio reading, it is assumed that the wall can withstand the maximum vibration with a PGA drift ratio value of $0.34 \mathrm{~g}$ without causing damage to the wall even though it has a low level of stiffness. Testing on the walls has a less high degree of precision. That may be due to factors other than PGA. That can affect the drift ratio on the walls, which have not been considered in this study.

Keyword - KNN, IMU Sensor, Wall Stiffness, PGA 


\section{PENDAHULUAN}

Penyebab getaran dibedakan dalam dua jenis yaitu; getaran mekanik adalah getaran yang ditimbulkan oleh sarana dan peralatan kegiatan manusia. Kemudian getaran seismik adalah getaran tanah yang disebabkan oleh peristiwa alam dan kegiatan manusia. Akibat yang ditimbulkan oleh getaran ini ada yang bersifat menguntungkan tetapi ada juga yang merugikan manusia [1].

Salah satu penyebab ambruknya suatu bangunan adalah karena kurangnya kekakuan dinding terhadap getaran. Rendahnya tingkat kekakuan dinding dapat mengakibatkan kerusakan pada bangunan saat terjadi gempabumi dengan skala yang besar. Terdapat banyak sistem pengukuran tingkat kekakuan pada bangunan namun belum mencapai tahap klasifikasi. Oleh sebab itu, diperlukan sistem yang dapat mengklasifikasikan tingkat kekakuan untuk mengetahui dampak getaran terhadap dinding agar dapat meminimalisir kerugian yang ditimbulkan dengan cara dibenahi lebih dini.

Pemantauan dan pengembangan tentang teknologi untuk mengukur kekakuan dinding terhadap getaran akan bermanfaat bagi masyarakat terutama jika terjadi bencana gempa bumi. Penelitian ini membuat sistem yang dapat mengklasifikasikan tingkat kekakuan dinding beton terhadap getaran berbasis IMU dengan masukan data non-linear dan jumlah data yang besar. Perancangan dan implementasi sistem sensor menggunakan sensor IMU [2]. IMU yang digunakan yaitu MPU-6050 (Accelerometer dan Gyroscope) sebagai alat pengukur pergerakan lateral pada dinding yang kemudian hasil sensing dari data tersebut diolah dan diklasifikasikan menjadi kategori kekakuan dinding rumah berbahan beton [3].

Metode yang digunakan pada penelitian ini adalah K-Nearest Neighbor (KNN). Penggunaan KNN bertujuan untuk menyelesaikan klasifikasi masukan data getaran berbentuk non-linear dan jumlah data yang besar. Algoritme K-NN merupakan sebuah metode untuk melakukan klasifikasi terhadap objek berdasarkan data pembelajaran yang jaraknya paling dekat dengan objek tersebut. Metode KNN merupakan metode yang cukup sederhana namun memiliki tingkat akurasi yang tinggi [4]. Teknik K-Nearest Neighbor dengan melakukan langkah-langkah yaitu, mulai input: Data training, label data traning, $k$, kemudian data testing.

\section{METODE PENELITIAN}

\subsection{Analisis Kebutuhan Sistem}

Pada penelitian ini akan dibuat sistem yang mampu mengklasifikasikan tingkat kekakuan dinding rumah berbahan beton dengan menggunakan metode K-Nearest Neighbor (KNN) ke dalam beberapa kategori (aman, rawan, bahaya, dan hancur) dengan data yang telah diolah dari sensor IMU pada kedua node yang berada di atas dan bawah kolom dinding [5]. Pengujian node sensor dilakukan pada dinding rumah berbahan beton dengan menjatuhkan beban berbobot dari ketinggian tertentu untuk mendapatkan getaran pada dinding. Penempatan node sensor disesuaikan dengan kebutuhan, node sensor ditempatkan pada kolom atas dinding bertujuan untuk mendapatkan pengukuran top inclination angle, sedangkan pada kolom bawah dinding bertujuan untuk mendapatkan pengukuran nilai ground acceleration, bottom inclination angle, displacement, dan drift ratio. Ilustrasi peletakan node sensor pada dinding dapat dilihat pada Gambar 1.

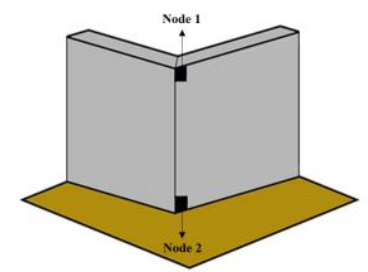

\section{Gambar 1 Ilustrasi Peletakan Node Sensor pada Dinding}

Nilai keluaran MPU6050 ini berupa nilai tegangan yang telah dikonversi oleh Analog to Digital Converter (ADC). Data yang diperoleh dari node 1 dan 2 hasil sensing IMU diubah dari percepatan menjadi perpindahan/pergerakan lateral. Untuk menentukan nilai kekakuan dinding 
dilakukan perhitungan untuk mendapatkan nilai Peak Ground Acceleration (PGA) dan drift ratio. Nilai ketahanan berupa nilai PGA drift ratio yang digunakan sebagai parameter untuk mengklasifikasikan tingkat kekakuan dinding ke dalam empat kategori (aman, rawan, bahaya, dan hancur).

Selanjutnya akan dilakukan klasifikasi menggunakan K-Nearest Neighbor (KNN) berdasarkan nilai PGA drift ratio sebagai masukan sistem. Sistem ini akan mengklasifikasikan tingkatan kekakuan dinding rumah berbahan beton ke dalam beberapa kategori. Sebelum melakukan perhitungan dengan metode K-Nearest Neighbor, terlebih dahulu harus menentukan data latih dan data uji. Kemudian akan dilakukan proses perhitungan untuk mencari jarak menggunakan Euclidean. Dengan mengelompokkan suatu data baru berdasarkan jarak data baru itu ke beberapa data/tetangga terdekat. Pertama sebelum mencari jarak data ke tetangga adalah menentukan nilai K tetangga (neighbor). Lalu, untuk mendefinisikan jarak antara dua titik yaitu titik pada data training dan titik pada data testing, maka digunakan rumus Euclidean. Kemudian menghitung jumlah data yang ada dihitung dari nilai K-tetangga tersebut. Diambil kelas dengan jumlah data terbanyak sebagai kelas pemenang dan diberikan label pada data uji. Tahap terakhir yaitu menghitung klasifikasi dari data dengan nilai $\mathrm{K}$ dan nilai jarak antar data uji dengan data lain yang sudah ada. Diagram blok rancangan sistem terdapat pada Gambar 2.

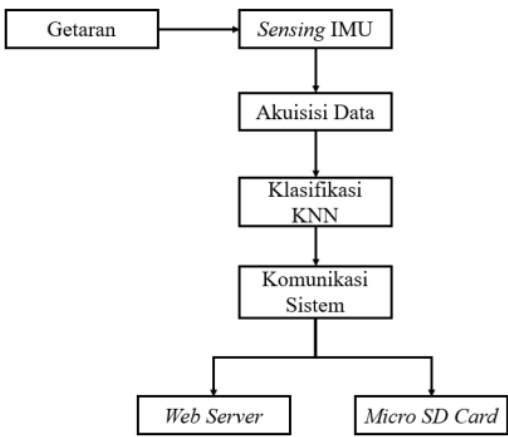

Gambar 2 Diagram Blok Rancangan Sistem

Setelah dilakukan analisa hasil tingkat kekakuan dinding maka data sensing getaran, akuisisi data, dan data klasifikasi KNN akan disimpan pada Micro SD Card dan database MySQL sehingga, dapat diakses untuk pengamatan data. Data sensing getaran, akuisisi data, data klasifikasi KNN dan hasil analisa tingkat kekakuan dinding akan ditampilkan pada GUI yang berbasis local host. Local host yang digunakan yaitu XAMPP untuk memproses file php yang akan digunakan untuk GUI.

\subsection{Perancangan perangkat keras}

Rancangan elektronik yang dibutuhkan disesuaikan dengan fungsi yang dibutuhkan oleh sistem. Terdapat 3 bagian utama dalam sistem elektronik, yaitu masukan, pengolah dan keluaran.

Pada masukan terdapat sensor IMU. Didalam IMU terdapat sensor accelerometer untuk membaca data percepatan transalasi dan gyroscope untuk membaca data kecepatan sudut. Untuk mendapatkan sudut rotasi pitch dan roll data percepatan translasi dan kecepatan sudut diproses dengan sensor fusion Digital Motion Processor (DMP) yang tersemat didalam perangkat keras sensor MPU-6050. Rancangan sistem elektronik terdapat pada Gambar 3.

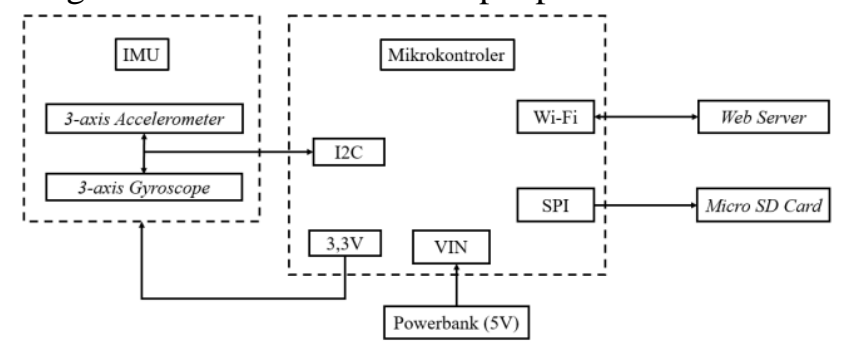

Gambar 3 Rancangan Sistem Elektronik 
Pengolah yang digunakan pada penelitian ini adalah mikrokontroler ESP32 dikarenakan spesifikasi prosesor yang memadai serta memiliki wireless connectivity berupa Wi-Fi dan Bluetooth. Mikrokontroler ini bertugas untuk melakukan pengolahan data dan perhitungan algoritme pada sistem node sensor.

Keluaran dari sistem node sensor ini adalah data Peak Ground Acceleration (PGA), drift ratio, displacement, inclination angle, dan hasil klasifikasi tingkat kekakuan dinding yang dikirimkan ke PC (database \& web server) komunikasi 2 arah dan module sd card komunikasi 1 arah SPI. Berdasarkan rancangan sistem elektronik di atas, maka rancangan untuk skematik pada board dapat dibuat. Penelitian ini sensor IMU menggunakan jalur $\mathrm{I}^{2} \mathrm{C}$ yang dihubungkan melalui SDA dan SCL pada mikrokontroller. Detail rancangan skematik elektronis node sensor terdapat pada Gambar 4.

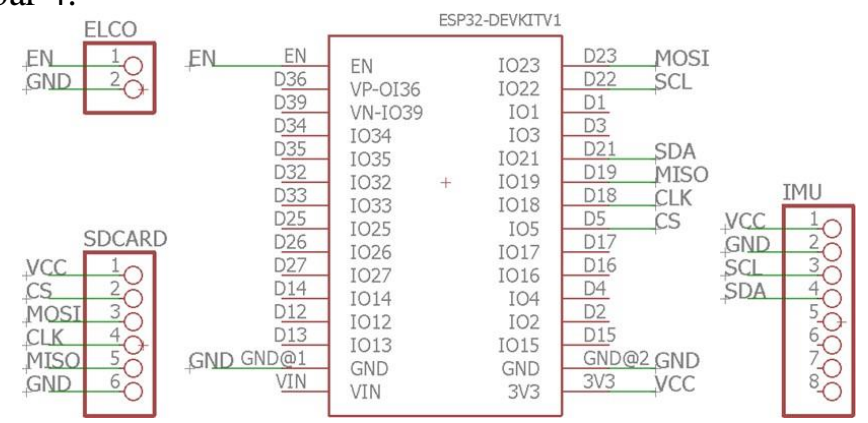

Gambar 4 Rancangan Skematik Elektronis Node Sensor

Rancangan node sensor dengan rangka wahana yang terbuat dari plat besi dengan dilapisi magnet sebagai media perekat board shield pada PCB dengan dinding. Plat besi yang dibuat memiliki panjang $9 \mathrm{~cm}$ dan lebar $6,4 \mathrm{~cm}$ dengan PCB yang sudah terdapat desain board shield dan komponen Mikrokontroler ESP32, IMU, Micro SD dan pin header yang telah terpasang. Perancangan instrumentasi elektronika pada penelitian ini menggunakan satu sumber tegangan, yaitu Power Bank.

\subsection{Akuisisi data}

Tahap akuisisi data dilakukan untuk memasukkan semua hasil sensing data oleh IMU MPU-6050 untuk diolah lebih lanjut. Akuisisi data dilakukan dalam lima tahap yaitu ground acceleration, inclination angle, displacement, drift ratio, dan nilai puncak.

\subsubsection{Ground Acceleration}

Ground Acceleration sama dengan amplitudo percepatan absolut terbesar yang tercatat pada accelerogram di suatu lokasi saat terjadi gempa bumi tertentu. Gempa bumi umumnya terjadi di ketiga arah (x,y, dan z). Oleh karena itu, ground acceleration sering dibagi menjadi komponen horisontal dan vertikal [6]. Nilai dari ground accleration diperoleh dari sensing IMU MPU-6050 yang berada di pojok bawah dinding. IMU terletak di pojok bawah dinding bertujuan untuk memperoleh nilai percepatan tanah dari getaran yang terjadi.

\subsubsection{Inclination Angle}

Inclination angle merupakan sudut pitch atau roll yang terukur oleh sensor IMU.

\subsubsection{Displacement}

Perpindahan merupakan masukan untuk menghitung nilai drift ratio. Pengangkatan di dasar dinding menyebabkan perpindahan vertikal dan rotasi di lokasi koneksi dinding ke lantai. Tingkat kekakuan ini dapat ditentukan melalui perbandingan antara besar beban lateral yang diterima dengan displacement yang terjadi pada dinding bangunan [7].

\subsubsection{Drift Ratio}

Drift ratio menjadi parameter penting untuk memperoleh nilai kekakuan dinding terhadap getaran. Drift ratio merupakan perbandingan nilai drift lateral maksimum terhadap ketinggian dinding. Uji tingkat kekakuan dapat dilakukan pada dinding dengan ketinggian yang

IJEIS Vol. 10, No. 2, October 2020 : $189-198$ 
berbeda-beda. Ketinggian dinding merupakan inputan data akuisisi, ketika dilakukan pengujian maka ketinggian dinding diinputkan pada program akuisisi data.

\subsubsection{Nilai Puncak}

Nilai tertinggi dari setiap parameter diambil, penggunaan nilai puncak dari tiap-tiap parameter dilakukan untuk menghasilkan perhitungan probabilitas tertinggi nilai getaran yang diterima oleh dinding.

\subsection{Perancangan klasifikasi K-Nearest Neighbor}

Pada penelitian skripsi ini, klasifikasi kekakuan dinding rumah berbahan beton terhadap getaran akan dirancang menggunakan metode K-nearest Neighbor (KNN). Langkah-langkah untuk menghitung metode KNN adalah, menentukan parameter (jumlah tetangga paling dekat), kemudian menghitung jarak (euclidean) setiap data latih terhadap data uji yang diberikan menggunakan rumus euclidean [8], setelah itu mengurutkan hasil perhitungan masing-masing jarak ke dalam kelompok yang mempunyai nilai jarak terkecil, dan terakhir mengumpulkan label terbanyak sesuai dengan urutan jarak terkecil dalam jangkauan sesuai dengan nilai yang ditentukan. Flowchart berikut menujukan proses pengklasifikasian untuk menentukan nilai keluaran pada aplikasi sebagai pemberitahuan kondisi kekakuan dinding. Flowchart klasifikasi terdapat pada Gambar 5.

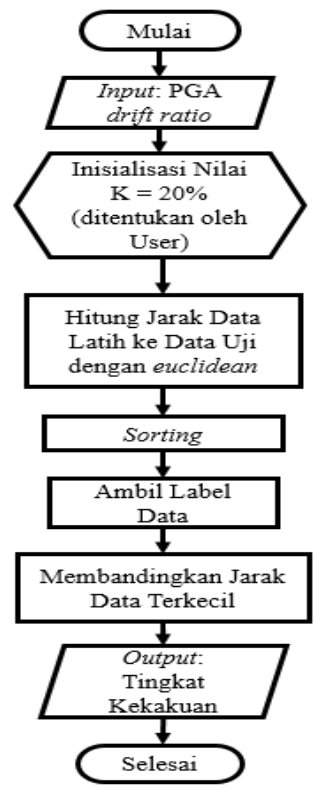

\section{Gambar 5 Flowchart Klasifikasi}

Ketika nilai PGA drift ratio telah didapatkan, sistem akan menentukan nilai $\mathrm{K}$ berdasarkan jumlah data latih yang ada pada basis data. Nilai K akan diambil sebanyak $20 \%$ dari jumlah data latih yang ada pada basis data. Jika nilai K sudah ditentukan, maka sistem akan melakukan proses perhitungan jarak data uji terhadap data setiap data latih yang ada pada basis data dengan menggunakan rumus euclidean. Setelah didapatkan jarak pada setiap data latih, sistem akan melakukan proses sorting data yaitu proses pengurutan data latih berdasarkan data jarak terkecil hingga terbesar. Proses selanjutnya yaitu mengambil label data terbanyak dari data ke-1 hingga data ke- nilai_k. Setelah penentuan jarak data terkecil maka proses klasifikasi selesai dengan output skor analisis klasifikasi tingkat kekakuan dinding.

Klasifikasi tingkat kekakuan dinding dengan K-Nearest Neighbor akan diketahui kemampuannya setelah sistem dilakukan beberapa pengujian menggunakan data uji sistem. Hasil informasi berupa nilai Peak Ground Acceleration (PGA) dan drift ratio yang diterima dinding terhadap getaran yang telah diolah dari sensing IMU dan akuisisi data menjadi nilai PGA drift ratio. PGA drift ratio merupakan masukan sistem untuk pengklasifikasian tingkat kekakuan dinding (aman, rawan, bahaya, hancur) dengan KNN. Terdapat empat tingkat 
kekakuan dinding berdasarkan nilai PGA drift ratio, setiap kategori memiliki batasan besaran PGA drift ratio dalam satuan galvano yang diubah menjadi satuan gravitasi. Kategori tingkat kekakuan dinding dipaparkan pada Tabel 1 berdasarkan skala intensitas gempa bumi BMKG.

Tabel 1 Kategori Kekakuan Dinding

\begin{tabular}{|l|l|l|}
\hline Kategori Kekakuan Dinding & Label & Nilai $\boldsymbol{P G A}_{\text {drift ratio }}(\mathrm{g})$ \\
\hline Aman & Hijau & 0.002957177017635992 \\
\hline Rawan & Kuning & 0.08973502674205769 \\
\hline Bahaya & Jingga & 0.170292607567314 \\
\hline Hancur & Merah & 0.5751199441195516 \\
\hline
\end{tabular}

\subsection{Perancangan Graphical User Interface (GUI)}

Data akuisisi dan hasil klasifikasi kekakuan dinding akan ditampilkan pada GUI yang berbasis local host. Local host yang digunakan yaitu XAMPP untuk memproses file php yang akan digunakan untuk GUI.

\section{HASIL DAN PEMBAHASAN}

Pada Bab ini disajikan hasil dari akuisisa data dan klasifikasi yang telah dirancang. Adapun pembahasan hasil dari penelitian ini meliputi beberapa pengujian sebagai berikut.

\subsection{Hasil akuisisi data}

Pengujian ini dilakukan pada tiga jenis dinding dengan ketinggian dan tingkat kekakuan awal yang berbeda-beda. Setiap pengujian akusisi data akan diambil 12 nilai data dari setiap dinding, sehingga total seluruh pengujian akuisisi data sebanyak 36 data. Pada drift ratio terdapat parameter inclination angle dan displacement. Inclination angle dibagi menjadi dua bagian pengukuran yaitu bottom angle untuk sudut pada bagian bawah dinding dan top angle untuk sudut pada bagian atas dinding. Untuk mendapatkan nilai PGA drift ratio diperlukan parameter drift ratio dan ground acceleration. Hasil akuisisi data dari pengujian yang dilakukan dapat dilihat pada Tabel 2, 3, dan 4.

Tabel 2 Hasil akuisisi data dengan ketinggian dinding $284 \mathrm{~cm}$

\begin{tabular}{|c|c|c|c|c|c|c|}
\hline No & G. Acc $(\mathrm{g})$ & Bot. Angle $\left({ }^{\circ}\right)$ & Top. Angle $\left(^{\circ}\right)$ & Displacement $(\mathrm{cm})$ & Drift Ratio $(\%)$ & PGA $_{\text {drift ratio }}(\mathrm{g})$ \\
\hline 1 & 0.0032 & 0.02 & 0.02 & 0.10 & 0.04 & 0.09 \\
\hline 2 & 0.0039 & 0.02 & 0.02 & 0.11 & 0.04 & 0.10 \\
\hline 3 & 0.0074 & 0.03 & 0.03 & 0.14 & 0.05 & 0.15 \\
\hline 4 & 0.0034 & 0.03 & 0.02 & 0.14 & 0.05 & 0.07 \\
\hline 5 & 0.0070 & 0.05 & 0.04 & 0.25 & 0.09 & 0.08 \\
\hline 6 & 0.0043 & 0.03 & 0.02 & 0.14 & 0.05 & 0.09 \\
\hline 7 & 0.0221 & 0.05 & 0.03 & 0.24 & 0.08 & 0.26 \\
\hline 8 & 0.0043 & 0.04 & 0.04 & 0.21 & 0.07 & 0.06 \\
\hline 9 & 0.0135 & 0.05 & 0.06 & 0.23 & 0.08 & 0.17 \\
\hline 10 & 0.0135 & 0.05 & 0.06 & 0.23 & 0.08 & 0.17 \\
\hline 11 & 0.0049 & 0.08 & 0.03 & 0.40 & 0.14 & 0.03 \\
\hline 12 & 0.0079 & 0.18 & 0.02 & 0.88 & 0.31 & 0.03 \\
\hline
\end{tabular}

Tabel 3 Hasil akuisisi data dengan ketinggian dinding $268 \mathrm{~cm}$

\begin{tabular}{|c|c|c|c|c|c|c|}
\hline No & G. Acc $(\mathrm{g})$ & Bot. Angle $\left(^{\circ}\right)$ & Top. Angle $\left(^{\circ}\right)$ & Displacement $(\mathrm{cm})$ & Drift Ratio $(\%)$ & $\boldsymbol{P G A}_{\text {drift ratio }}(\mathrm{g})$ \\
\hline 1 & 0.0042 & 0.05 & 0.06 & 0.23 & 0.09 & 0.05 \\
\hline 2 & 0.0314 & 0.06 & 0.04 & 0.29 & 0.10 & 0.32 \\
\hline 3 & 0.0172 & 0.08 & 0.04 & 0.33 & 0.15 & 0.12 \\
\hline 4 & 0.0226 & 0.06 & 0.05 & 0.28 & 0.11 & 0.21 \\
\hline 5 & 0.0215 & 0.06 & 0.08 & 0.28 & 0.11 & 0.20 \\
\hline 6 & 0.0291 & 0.05 & 0.06 & 0.24 & 0.09 & 0.33 \\
\hline 7 & 0.0156 & 0.05 & 0.04 & 0.23 & 0.09 & 0.17 \\
\hline 8 & 0.0359 & 0.07 & 0.08 & 0.33 & 0.12 & 0.30 \\
\hline 9 & 0.0354 & 0.07 & 0.04 & 0.32 & 0.12 & 0.29 \\
\hline 10 & 0.0203 & 0.08 & 0.05 & 0.38 & 0.15 & 0.14 \\
\hline 11 & 0.0078 & 0.08 & 0.06 & 0.37 & 0.14 & 0.06 \\
\hline 12 & 0.0039 & 0.03 & 0.06 & 0.14 & 0.06 & 0.07 \\
\hline
\end{tabular}


Tabel 4 Hasil akuisisi data dengan ketinggian dinding $248 \mathrm{~cm}$

\begin{tabular}{|c|c|c|c|c|c|c|}
\hline No & G.Acc $(\mathrm{g})$ & ${\text { Bot.Angle }\left({ }^{\circ}\right)}$ & Top Angle $\left({ }^{\circ}\right)$ & Displacement $(\mathrm{cm})$ & Drift Ratio(\%) & PGA $_{\text {drift ratio }}(\mathrm{g})$ \\
\hline 1 & 0.0165 & 0.03 & 0.03 & 0.12 & 0.05 & 0.34 \\
\hline 2 & 0.0049 & 0.03 & 0.03 & 0.13 & 0.05 & 0.09 \\
\hline 3 & 0.0056 & 0.03 & 0.03 & 0.13 & 0.05 & 0.11 \\
\hline 4 & 0.0068 & 0.04 & 0.05 & 0.16 & 0.07 & 0.10 \\
\hline 5 & 0.0079 & 0.03 & 0.02 & 0.15 & 0.06 & 0.13 \\
\hline 6 & 0.0070 & 0.02 & 0.02 & 0.09 & 0.04 & 0.20 \\
\hline 7 & 0.0079 & 0.03 & 0.02 & 0.12 & 0.05 & 0.16 \\
\hline 8 & 0.0140 & 0.06 & 0.07 & 0.27 & 0.11 & 0.13 \\
\hline 9 & 0.0049 & 0.06 & 0.08 & 0.25 & 0.10 & 0.05 \\
\hline 10 & 0.0039 & 0.08 & 0.05 & 0.35 & 0.14 & 0.03 \\
\hline 11 & 0.0015 & 0.18 & 0.04 & 0.76 & 0.31 & 0.05 \\
\hline 12 & 0.0073 & 0.09 & 0.07 & 0.38 & 0.15 & 0.05 \\
\hline
\end{tabular}

Dari hasil akuisisi data dapat diketahui bahwa nilai displacement berbanding lurus dengan nilai drift ratio. Namun, nilai drift ratio berbanding terbalik dengan nilai PGA drift ratio. Semakin tinggi nilai PGA drift ratio, maka semakin besar dampak getaran terhadap dinding. PGA drift ratio merupakan masukan sistem untuk pengklasifikasian tingkat kekakuan dinding (aman, rawan, bahaya, hancur) dengan KNN.

Dilakukan pengukuran awal ground acceleration, inclination angle saat posisi diam untuk mengetahui nilai error. Hasil nilai error saat node sensor berada pada posisi diam dapat dilihat pada Tabel 5.

Tabel 5 Hasil pengujian nilai error pada akuisisi data

\begin{tabular}{|c|c|c|}
\hline \multirow{2}{*}{ No } & \multicolumn{2}{|c|}{ Pembacaan Data Error } \\
\cline { 2 - 3 } & G. Acc $(\mathrm{g})$ & Inclination Angle $\left(^{\circ}\right)$ \\
\hline 1 & 0.0003 & 0.001 \\
\hline 2 & 0.0006 & 0.001 \\
\hline 3 & 0.0004 & 0.001 \\
\hline 4 & 0.0003 & 0.001 \\
\hline 5 & 0.0002 & 0.003 \\
\hline 6 & 0.0004 & 0.001 \\
\hline 7 & 0.0002 & 0.001 \\
\hline 8 & 0.0002 & 0.003 \\
\hline 9 & 0.0002 & 0.001 \\
\hline 10 & 0.0001 & 0.001 \\
\hline 11 & 0.0001 & 0.001 \\
\hline 12 & 0.0001 & 0.001 \\
\hline 13 & 0.0001 & 0.001 \\
\hline 14 & 0.0003 & 0.003 \\
\hline 15 & 0.0003 & 0.001 \\
\hline 16 & 0.0004 & 0.001 \\
\hline 17 & 0.0006 & 0.006 \\
\hline 18 & 0.0003 & 0.006 \\
\hline 19 & 0.0003 & 0.006 \\
\hline 20 & 0.0001 & 0.003 \\
\hline
\end{tabular}

Dari pengukuran nilai error pada Tabel 5, diperoleh nilai rata-rata dan standar deviasi ground acceleration yaitu $(0.0003 \pm 0.00015) \mathrm{g}$ dan untuk inclination angle yaitu $(0.002 \pm 0.0018)^{\circ}$.

\subsection{Hasil Pengujian Klasifikasi K-Nearest Neighbor}

Datasets yang digunakan untuk klasifikasi KNN adalah kategori tingkat kekakuan bangunan berdasarkan Skala Intensitas Gempabumi (SIG) BMKG untuk mengklasifikasikan tingkat kekakuan dinding beton terhadap getaran. Dari datasets tersebut sudah tervalidasi untuk dapat mengidentifikasi dan mengklasifikasikan tingkat kekakuan dinding. Tipe data skala tingkat kekakuan dinding berupa numerik sedangkan hasil klasifikasi berupa keterangan tingkat kekakuan dinding. 
Data latih yang digunakan sebagai basis data didapatkan dari proses ekstraksi nilai getaran asli terhadap dinding. Setiap data yang dihasilkan oleh dinding yang mendapatkan getaran menghasilkan nilai yang berbeda, tergantung pada tingkat kekakuan dinding. Data nilai getaran kondisi aman didapat dari pengujian pada dinding beton berusia baru ( $<10$ tahun) memiliki tingkat kekakuan yang tinggi serta masih sedikit terdapat retakan pada dinding, data nilai getaran kondisi rawan didapat dari pengujian pada dinding beton berusia menengah (11-30 tahun), dan data nilai getaran kondisi bahaya didapat dari pengujian pada dinding beton berusia tua (>30tahun) memiliki tingkat kekakuan yang rendah dan terdapat banyak retakan pada dinding yang ketika terjadi getaran kecil pun akan sangat berdampak pada dinding. Kategori hancur tidak terdapat pada label karena pengujian tidak dapat dilakukan pada dinding yang telah hancur, sehingga tidak memungkinkan. Pelabelan data diverifikasi dengan tabel dari BMKG terkait PGA drift ratio, sehingga label data (aman, rawan, dan bahaya) sudah tervalidasi.

Data latih pada penelitian ini sebanyak 27 data, yang terdiri dari 3 jenis data atau label yaitu label aman, rawan, dan bahaya. Penentuan 3 jenis label ini didasari dari kondisi yang terjadi pada dinding saat menerima getaran berdasarkan usia dinding, banyaknya retakan, tingkat kekakuan, serta diverifikasi dengan seismograf. Hasil perekaman data yang digunakan sebagai data latih dapat dilihat pada Tabel 6.

Tabel 6 Data Latih

\begin{tabular}{|c|c|c|c|}
\hline No & PGA drift ratio & Label & Kondisi \\
\hline 1 & $0-0.03$ & 1 & Aman \\
\hline 2 & $0.031-0.17$ & 2 & Rawan \\
\hline 3 & $0.18-0.36$ & 3 & Bahaya \\
\hline
\end{tabular}

Setelah label data ditentukan, maka perangkat mengakuisisi data getaran dan mengklasifikasikan tingkat kekakuan dinding. Keterangan merupakan hasil klasifikasi dari sistem. Hasil klasifikasi menggunakan K-Nearest Neighbor dapat dilihat pada Tabel 7.

Tabel 7 Hasil klasifikasi K-Nearest Neighbor

\begin{tabular}{|c|c|c|c|c|c|}
\hline \multirow{2}{*}{ No } & \multirow{2}{*}{ Label } & \multicolumn{4}{|c|}{ Pengujian } \\
\hline & & G. Acc $(\mathrm{g})$ & Drift Ratio (\%) & PGA drift ratio $(\mathrm{g})$ & Keterangan \\
\hline 1 & Aman & 0.0039 & 0.15 & 0.03 & Aman \\
\hline 2 & Aman & 0.0067 & 0.27 & 0.02 & Aman \\
\hline 3 & Aman & 0.0039 & 0.14 & 0.03 & Aman \\
\hline 4 & Aman & 0.0039 & 0.15 & 0.03 & Aman \\
\hline 5 & Aman & 0.0049 & 0.14 & 0.03 & Aman \\
\hline 6 & Aman & 0.0079 & 0.31 & 0.03 & Aman \\
\hline 7 & Aman & 0.0039 & 0.14 & 0.03 & Aman \\
\hline 8 & Aman & 0.0049 & 0.14 & 0.03 & Aman \\
\hline 9 & Aman & 0.0079 & 0.31 & 0.03 & Aman \\
\hline 10 & Rawan & 0.0032 & 0.04 & 0.09 & Rawan \\
\hline 11 & Rawan & 0.0039 & 0.04 & 0.10 & Rawan \\
\hline 12 & Rawan & 0.0034 & 0.05 & 0.07 & Rawan \\
\hline 13 & Rawan & 0.0070 & 0.09 & 0.08 & Rawan \\
\hline 14 & Rawan & 0.0172 & 0.15 & 0.12 & Rawan \\
\hline 15 & Rawan & 0.0042 & 0.09 & 0.05 & Rawan \\
\hline 16 & Rawan & 0.0078 & 0.14 & 0.06 & Rawan \\
\hline 17 & Rawan & 0.0039 & 0.06 & 0.07 & Rawan \\
\hline 18 & Rawan & 0.0049 & 0.05 & 0.09 & Rawan \\
\hline 19 & Bahaya & 0.0221 & 0.08 & 0.26 & Bahaya \\
\hline 20 & Bahaya & 0.0135 & 0.08 & 0.17 & Bahaya \\
\hline 21 & Bahaya & 0.0314 & 0.10 & 0.32 & Bahaya \\
\hline 22 & Bahaya & 0.0291 & 0.09 & 0.33 & Bahaya \\
\hline 23 & Bahaya & 0.0156 & 0.09 & 0.17 & Bahaya \\
\hline 24 & Bahaya & 0.0165 & 0.05 & 0.34 & Bahaya \\
\hline 25 & Bahaya & 0.0079 & 0.06 & 0.13 & Bahaya \\
\hline 26 & Bahaya & 0.0070 & 0.04 & 0.20 & Bahaya \\
\hline 27 & Bahaya & 0.0079 & 0.05 & 0.16 & Bahaya \\
\hline
\end{tabular}


Berdasarkan Tabel 7 rata-rata pembacaan PGA drift ratio oleh sistem pada label aman sebesar 0.0288 g. Rata-rata pembacaan PGA drift ratio oleh sistem pada label rawan sebesar $0.081 \mathrm{~g}$. Sedangkan, rata-rata pembacaan PGA drift ratio oleh sistem pada label bahaya sebesar 0.2311 g. Diasumsikan dinding dapat menahan getaran maksimal dengan nilai PGA drift ratio sebesar $0.34 \mathrm{~g}$ tanpa menimbulkan kerusakan pada dinding sekalipun memiliki tingkat kekakuan yang rendah.

Hasil pengujian getaran pada dinding berdasarkan data latih yang sudah ditetapkan dapat dilihat pada tabel. Pengujian nilai getaran berdasarkan kondisi dinding aman, rawan, bahaya, dan hancur dilakukan sebanyak 27 kali dan terdapat 0 kali kegagalan dalam proses pengklasifikasian kategori kekakuan dinding sehingga persentase keberhasilan sebesar $100 \%$ didapat dengan perhitungan persamaan [9].

$$
\begin{gathered}
\text { \%keberhasilan }=\frac{27}{27} \times 100 \%=100 \% \\
\text { \%kegagalan }=100 \%-0 \%=0 \%
\end{gathered}
$$

KNN mampu melakukan klasifikasi dengan masukan data berbentuk non-linear dan jumlah data yang besar. Dari pengujian pada dinding, diperoleh standar deviasi PGA drift ratio yaitu $\pm 0.0215 \mathrm{~g}$, yang artinya bernilai cukup besar, sehingga presisi sistem kurang baik. Presisi yang kurang baik ini terjadi karena PGA tidak selalu berbanding lurus dengan drift ratio. Seharusnya drift ratio berbanding lurus dengan gaya lateral [10]. Hal ini mungkin dikarenakan adanya faktor selain PGA yang dapat mempengaruhi.

\section{KESIMPULAN}

Berdasarkan hasil penelitian, implementasi dan pengujian, sistem yang dirancang mampu mengklasifikasikan tingkat kekakuan dinding kedalam beberapa kategori (aman, rawan, bahaya, dan hancur) dengan masukan data non-linear menggunakan metode K-Nearest Neighbor. Tingkat keberhasilan KNN mencapai nilai 100\%. Rata-rata pembacaan PGA drift ratio oleh sistem pada label aman sebesar $0.0288 \mathrm{~g}$. Rata-rata pembacaan PGA drift ratio oleh sistem pada label rawan sebesar $0.081 \mathrm{~g}$. Sedangkan, rata-rata pembacaan PGA drift ratio oleh sistem pada label bahaya sebesar 0.2311 g. Diasumsikan dinding dapat menahan getaran maksimal dengan nilai PGA drift ratio sebesar $0.34 \mathrm{~g}$ tanpa menimbulkan kerusakan pada dinding sekalipun memiliki tingkat kekakuan yang rendah.

Pengujian pada dinding mendapatkan tingkat presisi yang kurang tinggi. Hal ini mungkin dikarenakan adanya faktor selain PGA yang dapat mempengaruhi drift ratio pada dinding, yang belum dipertimbangkan dalam penelitian ini.

\section{SARAN}

Saran-saran yang dapat diterapkan untuk pengembangan penelitian ini, diantaranya Perlu adanya penambahan parameter penentuan tingkat kekakuan selain PGA dan drift ratio yang dapat mempengaruhi nilai kekakuan dinding yang belum dipertimbangkan. Perlu adanya penambahan variasi bobot beban dan ketinggian agar dapat memperoleh getaran yang lebih besar hingga mencapai tingkatan maksimal.

\section{UCAPAN TERIMA KASIH}

Ucapan terima kasih disampaikan kepada Lab. Riset Elektronika dan Instrumentasi, Departemen Ilmu Komputer dan Elektronika, Fakultas Matematika dan Pengetahuan Alam, Universitas Gadjah Mada yang telah memberikan dukungan fasilitas dalam penelitian ini. 


\section{DAFTAR PUSTAKA}

[1] Sucofindo, "Buku Saku Kesehatan dan Keselamatan Kerja", Kep.MENLH No:KEP49/MENLH/11/1996, 2002.

[2] A. Alphonsa and G. Ravi, "Earthquake Early Warning System by IOT using Wireless Sensor Networks", IEEE, 2016.

[3] R. Didik, M. Sukir, N. Ahmad, "Application of Single MEMS-Accelerometer to Measeure 3-Axis Vibrations and 2-Axis Tilt-Angle Simultaneously”, TELKOMNIKA, Vol.13, No.2, June 2015, pp. 442 450 ISSN: 1693-6930, 2015.

[4] N. Yadi, "Tugas Akhir Data Mining", Iterative Dichotomiser 3(ID3), 1-62, 2015.

[5] G. Lorant, "Seismic Design Principles"Retrieved May 10, 2020, from https://www.wbdg.org/resources/seismicdesign-principles, 2016.

[6] L. Xie, "Resources, Environment and Engineering II". (CREE 2015; L. Xie, Ed.). from https://books.google.co.id/books?id=-DUOCwAAQBAJ, 2015.

[7] P. W. Weng, Y. A. Li, Y. S. Tu, and S. J. Hwang, "Prediction of the Lateral LoadDisplacement Curves for Reinforced Concrete Squat Walls Failing in Shear," J. Struct. Eng. (United States), vol. 143, no. 10, 2017.

[8] B. Avelita, "Klasifikasi K-Nearest Neighbor", academia.edu/9131959/A, 2016.

[9] Arif. S, Abdul. M, Irma. N, "Rancang Bangun Alat Pendeteksi Kerusakan Bearing pada Kendaraan Roda Empat Menggunakan Metode KNN". POSITRON vol. 8,No.2, pp. 31-38, 2018.

[10] J. D. C. Kumar and L. Venkat, "Effect of Lateral Forces on Precast Shear Wall," Int. J. Civ. Struct. Eng. Res., vol. 3, no. 2, pp. 74-84, 2016. 